\title{
Alternative Dispute Resolution (ADR) in Matters of Igiogbe Inheritance Under Bini Native Law and Custom
}

\author{
A.A. ALABI \\ LL.B (Hons), LL.M, Ph.D, B.L, Lecturer, Department of Jurisprudence and International Law, Faculty of Law, \\ Ambrose Alli University, Ekpoma, Solicitor and Advocated of the Supreme Court of Nigeria \\ J.O. OTOGHILE \\ LL.B (Hons), LL.M, Ph.D, B.L, Deputy Registrar, (Litigation) High Court of Justice, Benin City, Nigeria.
}

\begin{abstract}
The law of succession as it relates to the inheritance of the property of a deceased person who dies testate or intestate mostly as it relates to the place of the eldest son in relation the inheritance of the 'igiobe' of a deceased Benin man under native law and custom has become an area of study that has received several pronouncements by the High Court, court of Appeal and Supreme Court, yet, the more the decisions of courts, the more new areas come up for explanations, clarifications and decisions. "Igiogbe" by the decision of the courts, is the house of the deceased where he lived, died and was buried and it cannot be inherited by or given to any child of the deceased other than the eldest male child who performs the fuel burial rites of his late father. It does not form part of the distributable estate of the deceased.The main findings of this work are firstly, that ignorance, poverty and greed are bane to the inheritance of Igiogbe of a deceased Benin man. Secondly, enforcement of the right of the eldest son to inherit his late father's igiogbe is prevalent where the first son is uneducated and poor. Thirdly, that the fact that courts void some wiles does not mean that a Benin man cannot write a will and distribute his properties therein as he wishes. A will still has place in relation to the inheritance of igiogbe under Benin native law and custom.It is therefore recommend that to ease quick settling of matters that has to do igiogbe inheritance, Alternative Dispute Resolution (ADR) mechanism rather than by litigation should be consider more appropriate. DOI: $10.7176 / \mathrm{JAAS} / 54-05$
\end{abstract}

Publication date: April $30^{\text {th }} 2019$

\subsection{Introduction}

The important role played by traditional institutions in the administration of justice was the subject matter of an empirical research work carried out by the Nigeria Institute of Advanced Legal Studies (NIALS) in $2013^{1}$. The findings from the research work revealed that traditional institutions, through their alternative dispute resolution mechanisms, resolve more disputes in the country than the formal court system. The problem of delay in the administration of justice is non existent under the traditional justice system as the disputing parties submit to the jurisdiction of traditional institutions and obey the decisions reached out of honour and respect for those institutions. However where a disputant fails to obey, the traditional institution lacks the wherewithal to enforce its decisions. The processes of traditional institutions which are based on the local customs and traditions of the people are very familiar to them and hence trusted by them; unlike the strange and foreign procedures of the formal court, system which remain a mystery to many. These findings have formed the basis for suggested measures to strengthen the role of traditional institutions in the country in view of their importance in building social harmony at the grassroots.

Procedurally, Nigeria's justice system is adversarial in nature. What this means is that the role of the judge in legal proceedings is that of an impartial arbiter who listens to the case on either side and decides on the basis of legal principles applicable to the case for the one with a greater merit. The presentation of facts supporting each case is the sole responsibility of the parties. The Judge is admonished to refrain from descending into the arena in the name of fact finding as that would be seen as making case for the parties.

In an inquisitorial system however, the Judge is ultimately interested in establishing the truth of the matter. He does this by getting as much facts from the parties as would enable him form a clear picture of the issues involved in the case and this forms the basis of his decision. The judge, under this system, may rely on what the parties present to him, or if he considers it necessary, examine witnesses of the parties or documents presented with the purpose of ascertaining the truth.

The thinking is that the adversarial system places more emphasis on form rather than substance, hence the focus on observance of procedural rule which distract from the substance of the case. This has been identified as one of the causes of delays in court proceedings. So much time is taken up dealing with procedural issues that by the time substantive issues are being addressed; a lot of time would have elapsed. As a matter of fact, it is hard to conceive of a system that is purely adversarial or inquisitorial. There is therefore the need for judicial reform and

\footnotetext{
${ }^{1}$ Restatement of Customary Law in Nigeria (Lagos: NIALS Press, 2013) Chapter 1
} 
transformation.

A purely adversarial system is no more capable of existing in the real world than a purely inquisitorial one, because though we may speak of a contest between the parties, the winner of contest between the parties, the winner of contested litigation cannot be determined objectively like the winner of a race: the Judge is bound to exercise his Judgment that is what he is paid to do.

Traditional institutions in the country are the back bone of justice

administration at the grassroot. They are the custodians of the custom and traditions of the people and exert enormous influence in cases which border on the observation of these customs and traditions. The place of traditional institutions in a multi-cultural society like Nigeria is heightened by the constant struggle for ethnic assertion by the various ethnic groups in the country. Traditional institutions help promote social harmony and co-existence between the various ethnic groups in the country.

Traditional institutions interface with the formal justice system through the Customary Court (C.C) and the Customary Court of Appeal (C.C.A). The Customary Court of Appeal is a superior court of record under the 1999 Constitution and is created by Section 280 of the 1999 Constitution of Nigeria (as amended). The jurisdiction of the CC.A. is provided for under Section 282 and is stated to be the Exercise of appellate and supervisory jurisdiction in civil proceedings involving questions of customary law ${ }^{2}$. The Customary Court of Appeal also exercises such jurisdiction and decides such questions as may be prescribed by the House of Assembly of the State for which it is established ${ }^{3}$.

Traditional institutions have not been fully utilized within the current framework for the administration of justice in Nigeria. Research has shown the extent of neglect of traditional institutions by the legal system in spite of the very significant role being played by these institutions in mediating disputes within their local communities as between the parties in the case brought before it. The posture of classifying anything relating to custom as inferior has also not helped matters. This attitude has significantly hampered the efficiency of traditional institutions in the administration of justice in Nigeria.

It must be noted that justice systems rest upon four principles or pillars that guide planning and operations. A functioning modem judiciary that supports healthy governance and provides justice is based on;

1. Accessibility to all citizens, business, civil society groups and government agencies, with variety as different avenues of providing justice services according to the needs of the parties, dynamics of the dispute, financial capabilities of the parties and the greater interests of society.

2. Transparent in operations with equal provision of justice and for all citizens and legal entities, procedural information should be made available to all the parties. The outcomes of judicial procedures are devoid of arbitrariness and not determined by the relative 'power' of the parties but rather by the merits of their cases, the public interest, the legal context as well as norms of fairness and equity.

3. Efficient in the provision of services and utilization of resources including systematic functioning of judicial processes and services provision of specialized and alternate forms of dispute resolution to increase appropriateness of proceedings and then decongest courts. When users of judicial services come to the courts and other justice related agencies, they are able to speedily obtain information, instructions, file proceedings, settle cases and have decisions upheld and enforced without undue delay, expenses or other hardship.

4. Strong institutional capacity-justice must be founded on strong institutional capacity that includes enhanced human resources, skills and knowledge, data collection and performance evaluation, service orientation, physical infrastructure, judicial independence, professional advancement and training and modernized technological capacity and processes.

\subsection{Meaning of ADR}

The acronym ADR means "Alternative Dispute Resolution". It is a group of flexible approaches to resolving disputes more quickly and at a lower cost than going to the court. It refers to the set of mechanisms a society utilises to resolve disputes without resort to costly adversarial litigation. It is a term, which has become associated with a variety of specific dispute resolution techniques such as Negotiation, Mediation, Arbitration, Conciliation, Mini-trial, Case Evaluation, Rent-a-judge and many other hybrid mechanism ${ }^{4}$. It is a process by which legal conflicts and disputes are resolved privately, other than through litigation in the public courts. The process provides an alternative to the conventional court room trial of causes and mailers. It is a system whereby

\footnotetext{
${ }^{1}$ Ibid.

${ }^{2}$ Section 282(1) of the 1999 Constitution (as amended).

${ }^{3}$ Section 282(2) of the 1999 Constitution (as amended).

${ }^{4}$ Goldberg, et al, Dispute Resolution 1992, Edn, Little Brown \&Co. Boston

U.S.A. see also Dele Peters, What is Alternative Dispute Resolution Lagos Dee-Sage Nigeria Ltd. 2005. P.10
} 
the judge or their party does not impose any decision on the parties. While he can express his opinions or views on the dispute between the parties, such opinions or views are merely advisory and the parties are at liberty to accept or reject such opinion.

The main role of the neutral third party in any of the ADR processes is to assist and guide the parties towards paving on their own and by themselves an amicable and generally acceptable solution to the dispute between them. The mediator, conciliator, facilitator, arbitrator, fact finder etc. does not impose his views of what is justice on the parties but allows them to find justice themselves i.e. by finding out what the interest of the parties are and then meeting that interest.

Some scholars of the alternative movement have expressed the view that the " $\mathrm{A}$ " in the acronym actually means "Appropriate" rather than "Alternative". Modern school of thought is of the view that the "A" should be "African" in which case ADR should be known as African Dispute Resolution or Appropriate Dispute Resolution. Whether it is Alternative Dispute Resolution, African Dispute Resolution or Appropriate Dispute Resolution, it is important that it invariably refers to diverse, friendly, cost-effective and non-adversarial methods of dispute settlement in the traditional African setting, as opposed to the litigation-centred approach of the western world.

These diverse African Dispute Resolution methods such as negotiation, mediation, - arbitration, conciliation, mini-trial, case evaluation and so on, help to maintain

peace and create an enabling environment for good relationship and neighbourliness and maintain on-going relationships ${ }^{1}$.

It must be noted that what is now ADR is not new to Africa. It has been our way of life and our own way of resolving and settling disputes in time past. The practice of alternative dispute resolution mechanisms in Africa predated the present western ADR movement which is only being "imported" to Africa what originally belonged to the African. It has been indigenous to African though now fine-tuned and relabeled.

The historical evolution of the modern ADR movement is very instructive. Beginning in the sixties and seventies a number of developed countries such as the United States of America, Australia and Canada witnessed an extraordinary' growth of interest in alternative form of dispute resolution. At the 1979 Pound Conference in Minnesota United States of America, leading jurists and lawyers came together to address popular dissatisfaction with the crowded justice system ${ }^{2}$. It was at this conference that Professor Frank E. A. Sander proffered the style of the "Multi-door Court House" as a radically different vision of the American justice system.

It must be noted that some African countries like Ghana and South Africa have embraced the use of ADR in their dispute resolution techniques and Nigeria cannot afford to be left behind by the wind of positive changes blowing across the world. Already there are many multi-door court houses in Nigeria. Edo, Imo and Enugu States have indicated their willingness to have their own multi-door court houses. The courts have not made enough use of the ADR mechanisms and this accounts for the high number of cases pending in the various courts and the clamouring for justice by plaintiffs and defendants as well. While the courts should not play an active part in the ADR mechanism, courts should however encourage both the plaintiffs and the defendants in cases involving the inheritance of "Igiogbe" to seek remedy to their problems through the ADR doors of resolving problems. This saves time, money and mental agony, torture etc. To the family of the deceased Bini man whose Igiogbe is litigated upon, no justice has been done as the once united family is now fragmented due to litigation.

Alternative Dispute Resolution is a process of settling disputes by means other than litigation. The word dispute is used interchangeably with the word "conflict". According to the Cambridge Advanced Learners Dictionary Second Edition dispute means a disagreement. The word "Alternative" refers to "Other options" to litigation. Compared to litigation, ADR offers a number of advantages and benefits given the time value for money, length of time and cost involved in judicial litigation. ADR offers wide spectrum or range of benefits in terms of cost saving, privacy, freedom of choice of venue, choice of law, preservation of good neighourliness, business and personal relations, finality of decision, speed flexibility of procedure, confidentially, autonomy of parties in choosing the arbitral tribunal and the relative rapidity and economy. Some definitions of ADR can also be defined as a process of resolving an issue susceptible to normal legal process by agreement rather than by imposing a binding decision. In ADR, where parties are able to arrive at agreement, compensation commensurate with the market value as at the date of negotiation is usually agreed upon. It is more valuable and economically realistic than to rely on unascertained monetary damage which may take a longer period to realize and even when realized, it would have been reduced in value as the Igiogbe in some cases falls into ruins due to lack of maintenance because of the court case. The tenants in some cases become divided as to who they pay rent to and in some cases they do not pay again but remains in the property with the connivance and consent of one of the parties in the dispute in court.

\footnotetext{
${ }^{1}$ Dele Peters Alternative Dispute Resolution (ADR) in Nigeria Principles and Practice Lagos: Dee-Sage Nigeria Ltd 2004.

${ }^{2}$ Aina Kehinde “Alternative Dispute Resolution (ADR) Solution to Courts Congestion” The Guardian Newspaper, Tuesday July 11997 at P24.
} 
The administration of the criminal and civil justice in Nigeria had remained on the brinks of collapse for so long. The average length of time to conclude Igiogbe cases from the Area Customary Court or High Court to the Customary Court of Appeal or Federal Court of Appeal and then to the Supreme Court is between twelve (12) to (16) sixteen years. Cases stretch longer and longer, with most cases taking a minimum of four years at every level. The delay is partly attributed to the laziness of counsel who file frivolous application and seek undue adjournment on flimsy excuses as a way of frustrating the opponents. The attitude of some judges to case management and administration of justice are equally disheartening and condemnable.

The use of ADR as a means of settling customary and commercial disputes is fast gaining acceptance in Nigeria $^{1}$. The Lagos multi-door court house, an initiative of the Negotiation and Conflict Management Group, an independent non-profit organization promoting the widespread use, prompt, effective and economies means of resolving disputes in collaboration with the Lagos State judiciary is the first Court connected ADR centre in Africa, Other notable ADR institutions are the Nigerian Branch of the chartered institute of Arbitrators, Institute of Mediators and Conciliators, Institute of professional Negotiators and Mediators, Institute of Maritime Arbitrators etc. etc. The statutory frame work is contained in the Arbitration and Conciliation Act ${ }^{\mathrm{a}}$. ADR is potentially useful in resolving disputes arising from the inheritance of Igiogbe and other inheritance matters in Edo State. This will necessarily entail the formal integration of ADR into the judicial system of administration of justice in Edo State as presently done in Lagos State and Abuja. The drafting of the civil procedure rules to accommodate and integrate ADR into the administration of justice in Edo State will decongest the courts of many inheritance and customary law related cases that can be easily resolved through the ADR process.

The major disincentive to wholesale acceptance of ADR by many families who struggle over the inheritance of Igiogbe is the absence of public or private acceptable enforcement of decision mechanism and the lack of trust and confidence on the ADR. This lack of trust has resulted in many families shirking away from embracing arbitration. Also the poor economic position and ignorance of the eldest son of the deceased Bini man is another factor for the lack of use of the ADR mechanism. The expensive option of litigation cannot be compared to the use of the ADR mechanism. Despite the advantages, it is wrong to assume that ADR is for all purposes better than or superior to litigation. In the dispute resolution arena, no one method, be it litigation or ADR, is in all aspects superior to the other. The effectiveness of any process is usually determined by the facts and circumstances of the particular case. What is important, therefore, is for practitioners to have the knowledge and skill to determine and adopt the process that best suits a given case. ADR offers a variety of options to litigants who dispute over the inheritance of their late father's Igiogbe and at the end of the decision the unity and peace in the family still remains intact. ADR can be started with arbitration and then mediation and conciliation. Among the three process mentioned, Negotiation is a common feature to them all. The ADR processes are negotiation, mediation, conciliation and arbitration. There are also processes such as the multi-door court house, med-arb and mini-trial among others.

\subsection{Negotiation}

This is an agreement bargaining process, without a third party intervention, whereby the parties to a dispute attempt to reach agreement or consensus on a disputed matter or potentially disputed matter. It also involves discussion on dealings about a matter with a view to reconciling differences and establishing areas of agreement, settlement or compromise that would be mutually beneficial to the parties or that would satisfy the aspiration of each party to the negotiation. Negotiation has been widely embraced in resolving several disputes in Lagos State. Dispute over Igiogbe inheritance is mostly common where there are two (2) or three (3) houses left by the deceased to be inherited by his children or where the man has more than one wife during his lifetime and has children from all the wives. In which case if he has one house, all the children or the senior from each of the wives will be craving for a share or partitioning of the Igiogbe. If he has more than one house, the senior son will be advocating for the claim of two of the houses as his late father's Igiogbe. Herein lies the problem but this problem or dispute or crisis can be negotiated after a point inspection of all the properties to the children from the other wives while the eldest son inherits the Igiogbe as of right and proceeds from the late mans account is used to buy land for the children of the other wife. Where negotiation succeeds and compensation paid, negotiation is likely to result in a win-win situation for both parties. If negotiation is rejected, further negotiation may occur, or in most cases the members of the family not satisfied with the negotiation will then resort to litigation. The case is litigated after failure of negotiation.

In order to achieve a successful negation, it is important for the parties or family members to secure the services of legal and technical experts to assist in the determination, assessment and preparation of prenegotiation terms and if necessary, to be part of the negotiation team. Although it may not be necessary that the experts must be members of the team but if the need for the services of experts arises during negotiation, the

\footnotetext{
${ }^{1}$ Agu Vlkewibe (1991) 4WLR (Pt. 180) 385; Nwuka V Nwache (1993)5NWLR(Pt.295)308

${ }^{\text {a }}$ Cap A18 Laws of the Federation of Nigeria 2004.
} 
expert may be consulted without being necessarily called to the negotiation table. It is equally important that the parties to the negotiation must be persons who has the authority and capacity to bind the parties by the decision reached. A junior member of a family might not have the power to bind the family during negotiation. The representative must have the authority to accept or reject decisions that are binding. This is so because lack of authority is one of the problems in negotiation. This often results in payment of compensation to wrong parties ${ }^{1}$. In practice, there are several approaches to negotiation and these include competitive, positional, collaborative or cooperative.

Any approach or approaches may be utilized depending on the circumstances. An approach to negotiation that attempts to take the best elements of competitive bargaining and the best elements of co-operative bargaining is a principled negotiation. Finally, negotiation must be approached with the requisite transparency in order for the family members to resolve their differences. A negotiation conducted in an atmosphere of honesty, transparency and fairness would produce an out come that will be mutually satisfactory to both parties.

\subsection{Mediation}

This is a voluntary and confidential process in which a neutral person, the mediator, assist disputing parties to clarify issues, develop options and work towards a mutually beneficial resolution. Mediators usually refrain from suggesting an outcome or solution. A mediator must not judge the disputing parties, and must refrain from giving advice. Parties are instead encouraged to find their own creative solutions to their conflict. If the parties can find their own solutions, they are more likely to be sustainable. Mediators are either volunteers or paid professionals, but work directly for the local or national courts or justice related ministries of the state or professional bodies and are trained by, supported by and answerable to the public authorities. Court annexed mediation systems are often under the direct supervision of one or more judges or judicial oversight bodies. Judges and their staff lead the planning, management and guidance of the court annexed mediation system and they collaborate with mediators and play oversight functions. Mediators work hand-in-hand with local authorities such as police, communal courts or religious authorities or justices of peace for the purpose of referral of cases. Additionally, agreements reached by the disputant parties in court annexed programs, sometimes have their agreement reviewed and approved and if necessary enforced by the formal justice system as Judgment of Courts.

No law prohibits mediation in Nigeria. Instead some edict, rules of court, Acts, Laws, Rules of professional conduct and constitution of organizations e.t.c. permits judges to encourage the parties to resort to ADR process. As a general rule, judges in Nigeria are not allowed to mediate from the bench. However, court- connected and mediated agreements are registered and enforced through the courts and once this is done res jusdicata applies

It should be noted that section 17 of the Federal High Court Act $^{\mathrm{b}}$, provides that in any proceeding in the Court, the court may promote reconciliation among the parties thereto and encourage and facilitate the amicable settlement thereof.

Section 18 of the High Court $\mathrm{Act}^{\mathrm{c}}$, provides that where an action is pending, the court may promote reconciliation among the parties thereto and encourage and facilities the amicable settlement thereof.

Order 25 (2)(c) of the High Court of Lagos State Civil Procedure Rules 2004 provides for promoting amicable settlement of the case or adoption of alternative dispute resolution.

Rule $15(3)(d)$ professional conduct for legal practitioners, 2007 provides that in his representation of his client, a lawyer shall not fail or neglect to inform his client of the options of alternative dispute resolution mechanisms before reporting to or continuing litigation on behalf of his client

Mediation is an important tool that helps to resolve dispute peacefhlly particularly where parties could not agree among themselves. Mediation offers a unique opportunity for both the eldest son and the family members to resolve grey areas in order to facilitate the much needed peace in the family. Mediation is a process of resolving disputes with the aid of a neutral third party. The role of the neutral third party involves assisting the parties privately and collectively, to identify the issues in dispute and look for ways to resolve the dispute. Often the mediator will encourage the parties to also exchange those summaries with each other. Unlike arbitration, Mediator is not empowered to decide any dispute, accordingly, mediator may meet privately and hold confidential and separate discussions with the parties to a dispute. This is known as "holding caucus" in mediation. The mediator's sole function is not to decide the issue or determine right or wrong, but to help the disputants resolve their conflicts consensually. Like negotiation, mediation is a participatory alternative that allows parties to retain control over the process and outcome. Mediation may be compulsorily provided for under the Laws or by the court rules or it may be voluntary by agreement of the parties.

\subsection{Conciliation}

This is the Judge initiated practice of guiding the litigants to create an equitable negotiated settlement instead of

\footnotetext{
${ }^{1}$ Ekpere V Afrorije (1972) 1 All NLR (Pt 1) 228

${ }^{\mathrm{b}}$ CAP, F12 laws of the Federation of Nigeria 2004

${ }^{c}$ Cap 510, Laws of Federation of Nigeria (ABUJA) 1990
} 
proceeding to trial. Conciliation sometimes incorporates suggestions for resolution. Conciliation can be a part of normal judicial proceedings. When negotiation fails, conciliation offers another opportunity for parties to reach an out of court settlement. Conciliation can be seen as an alternative to arbitration, or the preparation of the groundwork towards arbitration in the event that conciliation fails. Conciliation is the adjustment and settlement of disputes in a friendly, non-antagonistic manner ${ }^{1}$. In conciliation, the conciliator doest not impose a ruling, which is what happens in arbitration as they impose decisions. The process of conciliation is regulated by sections 39 to 42 of the Arbitration and Conciliation Act (ACA) and the Arbitration law ${ }^{\mathrm{e}}$. In conciliation, parties seek amicable settlement of any dispute arising out of or in relation to contract or other legal relationships. When the parties agree to settle by conciliation they may elect that the conciliation rules contained in Schedule III of the ACA be applicable, or they may choose to exclude its application or may even vary the rules altogether. The party who wants to use conciliation sends a written request in writing to the other party stating the subject matter of the dispute.

If accepted, the parties refer the dispute to a conciliatory body consisting of one or three conciliators appointed by the parties to the dispute. The conciliation hearing starts on the day the request to conciliation is accepted by the other party ${ }^{2}$.

All conciliators must be appointed by the parties. This is one major difference between conciliation and arbitration. In arbitration, the third arbitrator is appointed by the two arbitrators. Where there is to be one conciliator, he is appointed jointly by the parties. If there are to be three, one is appointed by each of the parties and then the two parties appoint the third conciliator jointly ${ }^{3}$.

In conciliation, the conciliator after hearing the parties submits his finding, opinion or terms of settlement to the parties. He does not impose it on them. The parties can be represented by legal practitioners during the hearing if they so desire ${ }^{4}$. When the parties agree to the terms of settlement, then a record of settlement ${ }^{5}$ is drawn up for the parties who then signs them. If they do not agree they may then submit the dispute to $\operatorname{arbitration}^{6}$ or litigation. Once the record of settlement is signed by the parties and the conciliator, it becomes a binding and enforceable document. The parties are not prejudiced by the conciliation proceedings if they later choose to go to court?

\subsection{Arbitration}

Arbitration is the process by which the parties on their own volition refer their disputes to an impartial third person selected by them for a resolution or decision based on the evidence and arguments to be presented before the arbitral tribunal ${ }^{8}$. This is the process where private individuals or panel outside of the court system determine the legal and or technical merits of a dispute and determine an arbitral award, which may be binding or nonbinding. Arbitration functions much like normal judicial processes. Under the High Court of Lagos State Procedure Rules, 2003, a pre-trial judge may by the agreement of the parties refer any dispute for arbitration. Edo State High Court Civil Procedure Rules also provide for Arbitration. ${ }^{\mathrm{f}}$ There are basically three types of arbitration. (1) voluntary or agreement arbitration (2) arbitration by order of court, and (3) statutory or compulsory arbitration. Under the voluntary arbitration, the parties agree to refer their present and future disputes to arbitration or arbitrator appointed by them or court, instead of a court of law (litigation). Under the arbitration by order of court, the court is empowered to refer any matter pending before it to arbitration ${ }^{9}$. In the third type of arbitration, arbitration is usually imposed by statute as under Trade Disputes

The court or a judge may order that a writ of subpoena and testificandum or of subpoena duces tecum shall issue to compel the attendance before any arbitrator or umpire of a witness wherever he may be within Nigeria. The court or judge may also order that a writ of habeas corpus and testificadum shall issue to bring up a prisoner for examination before any arbitrator or umpire.

The arbitrator or arbitrators may appoint an umpire at any time within the period during which they have power to make an award. The arbitrator or arbitrators shall make their award in writing within three months after having been called on to act by notice in writing from any party to the agreement or submission or on or before any later day to which the arbitrators, by any writing signed by them, however they may from time to time

\footnotetext{
${ }^{1}$ Section 38 of ACA

${ }^{\mathrm{d}}$ LFN, 2004

${ }^{\mathrm{e}}$ Cap 10 laws of Bendel State of Nigeria 1976 now applicable to Edo State

${ }^{2}$ Section 39 of ACA

${ }^{3}$ Ibid Section 40 of ACA

${ }^{4}$ Ibid Section 41 of ACA

${ }^{5}$ Ibid Section 42 of ACA

${ }^{6}$ Ibid Section $42(3)$

${ }^{7}$ Ibid Section $42(4)$

${ }^{8}$ Orojo and Ajomo; Law and Practice of Arbitration and Conciliation in Nigeria, $3^{\text {rd }}$ Edn. Lagos: Mbeyi Associates. P. 37

${ }^{\mathrm{f}}$ Cap 10 volume 1 laws of Bendel State of Nigeria 1976 (applicable in Edo and Delta State).

${ }^{9}$ Ezejiofor, G. The Law of Arbitration in Nigeria (Nigeria: Longman, 2005) p. 12
} 
enlarge the time for making the award. If the time allowed for the award or extended time expire and the arbitrators cannot make an award then the umpire shall make his award within one month after expiration of the time allowed.

In some cases of arbitration decision can be reached without oral evidence given and the whole arbitration will be based on documentary evidence by the agreement of the parties. By this process very short period will be spent to dispose off the mailer by a sole arbitrator. Arbitration has its advantages over court litigation: there is lack of publicity in relation to the proceedings; hearing is expeditious as the vexatious delays in litigation and procrastination are avoided. It provides for amicable settlement between the parties. All court rules whether High Court, Customary Court or the Magistrate Court should provide for arbitration in their rules of court. Where an arbitral award is made and the party against whom the award is made is ready and willing to perform as stated in the award, there is usually no problem. Problems however, arose where the party against whom the award was made failed to co-operate or do as was stated in the award. This will then make the party to whom the award was in his favour to seek the assistance of the court for the enforcement of the award. So, the enforcement of the award becomes a problem. The other party may try to void the award on the ground that the award was improperly procured or on the ground of misconduct of the arbitrator. This will again lead to prolonged court cases. Apart from the problem of enforcement of the award, there is the problem associated with the right of the party that losses in the arbitration to apply to court to set aside the award and where this application to court succeeds the time and money spent in arbitration becomes a waste as it is lost. Speaking on whether disputes submitted to customary arbitration by consent of both parties is conducive and binding, the court has held that where disputes or matters in difference between two or more parties are by consent of the disputants submitted to a domestic forum, inclusive of arbitrators or a body of persons who may be invested with Judicial authority to hear and determine such disputes and matters submitted for investigation in according with customary law and general usages, and a decision is duly given, it is as conclusive and unimpeachable as the decision of any constituted court of the land.

Such a decision is consequently binding on the parties and the courts in appropriate cases will enforce it. ${ }^{1}$

A decision of native arbitration, although not a competent court with Judicial powers but if accepted by the parties, could create estopel by way of res judicata. ${ }^{2}$

One of the many methods of setting disputes under the customary law is to refer the dispute to the family head or an elder or elders of the community for a compromise solution. When the dispute has been investigated at the meeting and in accordance with customary law and a decision is given, it is binding on the parties whether it is made by the arbitrators of the umpire. Also oath taking was one of the methods of establishing the truth of a matter and is known to customary law. ${ }^{3}$

A written agreement to submit present or future differences to arbitration whether an arbitrator is named therein or not shall be irrevocable, except by leave of the court or a judge or by mutual consent, and shall have the same effect in all respects as if it had been made an order of court unless a contrary intention is expressed therein. The court may order stay of proceedings in a matter already in court and refer it to Arbitration.

The court may remove an arbitrator who has misconducted himself where an arbitration or award has been improperly procured, the court may set the award aside. An award on a submission may by leave of the court or a judge, be enforced in the same manner as a judgment.

Arbitration as an alternative mode of dispute resolution has for decades been given legal backing as can be seen in seen in the Arbitration and Conciliation Act of 1988 and S. 4(2) of the Arbitration and Conciliation Act, $1990^{\mathrm{g}}$ where it was stated that "an arbitrator's award under the provisions of Section 4(2) of the Act when filed in court should for all purposes have been the force and effect as a judgment".

This is also supported by order 22 Rule 13 of Abuja High Court (Civil Procedure) rules 1985 which provides "if no application is made to set aside the award or to remit any of the matters referred for reconsideration or if the court shall have refused any such application either party may file the award in court, and the award shall there upon have the same force effect for all purposes as a judgment". This provision should be included in the Edo State High Court Civil Procedure Rules. It is therefore clear and without any doubt, that an arbitral award made by an arbitrator to whom a voluntary submission was made by the parties to the arbitrations is binding between them. ${ }^{4}$

A court of law cannot make an award by an arbitrator as its own judgment because they are at par. The arbitrator cannot enforce the award but the court can enforce it as Judgment if one of the parties has filed it in court for enforcement.

\footnotetext{
1(1) Nka v. Onwu (1996) 40/41 LRCN 1306, (2) Anjaku v. Nnamani, 14 WACA 359, (3) 3.3 of Arbitration in Law Cap 10 Laws of Bendel State 1976 as applicable to Edo State. ${ }^{(4)}$ Joseph Harbi v. Opanin Kwasi 13 WACA 81

${ }^{2}$ Akpan v. Otong (1996) 2144 LRCN 2177; Ohaeri and Ors v. Akabuezes (1992) 7 LRCN 163

${ }^{3}$ Ume v. Okoronkwo (1996) 43 LRCN 2017

g Cap 19 LFN, 1990

${ }^{4}$ Ojibah v. Ojibah(1991) 5 NWLR pt $191 @ 296$
} 
The award once filed in court shall be recognized and enforced by the court on the application of any of the parties to the award unlike consent Judgment arrived at where parties seek leave of court to settle out of court and when they settle the terms of settlement is drawn up signed by the parties and filed in court. Unless and until the court makes the terms of the settlement a judgment of the court, it is not binding and cannot be enforced. ${ }^{1}$

\subsection{The Multi-Door Court House}

A multi-door house is a court of law in which facilities for ADR are provided. It is the formal integration of ADR into the court system. Therefore instead of having a court system with only litigation as the only avenue for dispute resolution, the multi-door court offers the parties to the dispute the choice of other ADR processes that may be appropriate for the particular case. It should be noted that the multi-door court house is a concept and not the building or department where ADR is practiced within the court premises. It is not ADR section in the court premises. It is a way of recognizing the availability of ADR process as part of the process. It is a way of recognizing the availability of ADR process as part of the justice delivery system in a particular jurisdiction. Once ADR is officially integrated into the judicial system with trained manpower, then a multi-door house exist even if there is no building erected as a multi-door court house.

The idea of a multi-door court house was first presented in 1971 by Professor Frank Sander of the Harvard School.

This was to be a means of decongesting the court and ensuring greater efficiency of the judicial system. To him it is not every matter that there is disagreement between the parties that should go to litigation and be listed in the courts hearing list. Others can be settled best by ADR.

The idea of multi-door court house is fast gaining ground in Nigeria with the establishment of the Abuja and Lagos multi-door court houses. It is suggested that the ideal of multi-door courts house should be embraced by all the State in the Federation especially Edo state where cases of inheritance of Igiogbe and other customary law and succession cases are very rampant. This will ensure speedy disposal of the disputer or cases which normally takes twelve (12) to sixteen (16) years in litigation from the first courts to the last court.

\subsection{Mediation-Arbitration (med-Arb)}

By this process, the parties agree in advance that their dispute would be resolved by mediation, and if that fails, then by arbitration. There are no fixed rules on how the process should be conducted. It is also possible to mediate during the course of the arbitration or mediate after the arbitration hearing has been concluded but before an award had been issued or made. It is possible for the parties to arbitrate some issues in the dispute and mediate on the remainder of the issues in dispute. In med-Arb. The parties can adopt procedures which best suits them to resolve the dispute.

\subsection{Mini-Trial}

This is a hybrid of mediation and the traditional settlement by negotiation. It is a completely voluntary procedure normally started by the parties themselves although judges may suggest or encourage it even where suit has already been filed in court. This process involves the parties bringing in one high level executive officer from each side of the dispute plus one neutral adviser who may be a retired judge or a non- judicial officer with an experience in the subject matter in dispute. The officers from each of the side must not have been involved in previous efforts to settle the dispute and they must have the authority of the parties to agree on a binding decision. Mini-trial can be with or without lawyers representing each side. Where lawyers are involved, the in house lawyers of the parties make a short presentation of the case of their clients in the presence of the executive representative of the case after which the executive officers then try to reach a settlement by negotiating a settlement with the advice and direction of the neutral officer. This negotiation of settlement by the respective executives or head or leader from each group makes this process unique and its decisions binding on the parties. This process reduces the length of the dispute and the legal fees to be paid if any is to be paid.

\subsection{The Law Clinic}

The idea of a law clinic borrows from the setup of a clinic in the medical profession where patients with all manner of ailments can come and get treatment. It is a platform to provide free legal services to indigent persons in Nigeria who are in desperate need of such services and have no means of obtaining it. The objective of the clinic is to provide an avenue for public spirited advocates to meaningfully contribute to the debate on access to justice; and directly engage with the administration of justice in the country as a way of testing some of the research positions for example the issue of the justifiability of chapter 11 of the 1999 Constitution of Nigeria (as amended). Whether the voiding of the will of a deceased Benin man that gives out his Igiogbe to the person of his choice who is not his eldest son does not offend the provisions of the constitution as regards the right to own

\footnotetext{
${ }^{1}$ Sections 29, 30, 31, 32 and 34 of the Arbitration and Conciliation Act Cap 19 Laws of the Federation of Nigeria, 1990.
} 
a property and to do whatever he likes with the said property.

\section{What Do We Do To Make ADR Work In Nigeria}

The effective workings of ADR in Nigeria, would require the setting in place certain institutional framework ${ }^{1}$ which include the following.

(1) The enactment of laws by the legislature to give legal backing to the use of ADR in courts, much so that once a matter is resolved outside the forum of the court or through the ADR process and the terms of settlement is reduced into writing and duely signed by the parties, non of the parties should be allowed to go to court again on the same dispute except on appeal. Such legislature provision should have the same effect as the rule against double jeopardy in the Nigerian Constitution ${ }^{2}$.

(2) There should be an establishment of an institution called an ADR centre e.g. "The Lagos multi-door court house" and the "Abuja multi-door court house". This should be established in the three senatorial districts in Edo State.

(3) There should be institutions for the training and re-training of the ADR staff or personnel of the centres e.g. mediators, arbitrators, facilitators etc.

With the enactment of the laws, the establishment of a centre and the training of the personel to handle the mechanism/workings of the system, then cases can then be referred to the centre by courts suo motu e.g. cases involving members of the same family; or the parties can themselves refer their matters to the centre instead of court. On the receipt of consent form duly signed by the parties and agreeing on mediation i.e. the use of ADR, the ADR official will then make available to the parties a list of. mediators. The parties will then select the mediator or mediators of their choice from the list. If they are unable to agree on one, the ADR official may assist them in selecting one. Once a mediator is selected a day agreeable by all the parties and the mediator is then fixed for hearing of the mediation. Each mediation session is not to last for more than two hours and every effort should be made to complete each case by an average of three mediation sessions. If settlement is reached at the end of the mediation, the parties may be encouraged to make their own agreement in writing stating clearly the terms of the settlement. The matter is sent back to The trial judge who ordered the mediation and he will enter the fact that the case has been settled and state the terms of settlement in his record book. Only the record of settlement will be kept in court all other records are then destroyed so as to ensure confidentiality.

If, however, settlement or mediation breaks down, that fact will be recorded by the mediator. The mediator will state briefly why settlement broke down without blaming any of the parties for the break down. The case will then be sent back to the trial court for trial.

\section{Conclusion and Recommendations Conclusion}

The above stated and discussed Alternative Dispute Resolution (ADR) mechanisms which are by no means exhaustive gives us reasons to hope that a bright future lies ahead for the administration of Justice in Edo State in particular and Nigeria in general.

However, a lot still needs to be done especially in the context of improving public perception of transparency in the Judicial process; strengthening the efficiency of all the components engaged in the administration of justice, encouraging a greater synergy amongst others.

In the struggle for who inherits the Igiogbe of a deceased Bini man in the family, it is suggested that ADR should be resorted to instead of the present process of litigation which has turn many families apart and make brothers and sisters of the same family enemies for life after the court judgment. The years of litigation will be drastically reduced with the use of ADR. Money will be saved either from filing of papers for litigation or as legal fees for lawyers who handle the case from the court of first instance to the Supreme court as the case may be. ADR will not only save time and money but will also help to maintain the good existing relationship between the parties in dispute.

The ADR mechanism if properly implemented, has the potentials to positively address most of the major problems facing the administration of justice system in Nigeria as the system is less expensive, not time consuming, affords the parties the opportunities to choose their judge or mediator and promotes good neighbourliness and peace. Also of note is that under the ADR it is a win/win situation for both parties.

Under the present adversarial (litigation) system unlike the ADR system there are the following disadvantages;

1. Winner and loser

2. The winner takes all

\footnotetext{
${ }^{1}$ Hon. Justice S.A. Brobbey: "Use of ADR in Ghana judiciary" available at www.worldbank.ora/wbi/governance/judidary. visited on the $26 / 4 / 18$

${ }^{2}$ Section 36(9) of the 1999 constitution of Nigeria.
} 
3. The important thing is about justice or it is about what the law say and not settling the dispute between the parties.

4. The right of the parties is paramount. It is my right syndrome.

5. There is no community involvement in the dispute resolution

6. Peace and good neigbourliness in the family and community is not of primary importance.

7. The parties see themselves as enemies and they hardly communicate with each other before and after judgment.

8. The parties do not agree on the decision it is forced on them and binding on them.

9. It is expensive and more time consuming.

10. The parties have no say as to who decide their matter as a Judge, Arbitrator, Mediator e.t.c

\section{Advantages of ADR include the following:}

1. Strengthens judicial modernization efforts.

2. Reduces delay in hearing of cases as it reduces the number of cases that go to court and thereby leading to court decongestions.

3. Increases access to justice for the poor. ADR proceedings are held where the parties agree to hold them. This is unlike litigation where the parties have no choice as to the venue and who the judge will be.

4. Reduces cost of justice for all users i.e it is less costly/cheaper

5. Preserves, improves or restores relationships among disputants in view of the relative speed of ADR mechanisms

6. Supports economic development by reducing costs of disputes and increasing certainty of investments.

7. Increases satisfaction of the uses with justice system.

8. ADR mechanism function with less formality than typical court proceedings, can be offered in the language of the disputants. It is more flexible.

9. Provides solutions that are equitable and responsive to the needs of the disputants. Results more in win/win situation for the parties and helps to build relationships even after the award.

10. It provides an alternative or alternative forum for some cases that would have otherwise languished in the courts.

It must be noted that under the present day justice system the courts have held that where an arbitration under customary law is pronounced valid and binding, it would be repugnant to equity and good conscience to allow the losing party to reject or resile from the decision of the arbitrators to which he has previously agreed. Also where parties to an agreement make provisions for arbitration before an action can be instituted in a court of law, any aggrieved party must first seek the remedy of arbitration before going to court.

Where a body of men be they chiefs or otherwise, act as arbitrators over a dispute between two parties, their decision shall have a binding effect on the parties if it is shown firstly that both parties submitted to the arbitration, secondly that the parties accepted the terms of the arbitration and thirdly that they agreed to be bound by the decision. Such decisions has the same authority as the judgment of a judicial body and will be binding on the parties and could be relied upon to establish a plea of estoppel.

Also a valid award on a voluntary reference to the multi door house no doubt operates between the parties as a final and conclusive Judgment upon all matters referred. It should be remembered that when parties decide to take their matter to arbitration, they are simply opting for an alternative mode of dispute resolution.

The writers strongly advocates the use of the ADR more in matters of Igiogbe inheritance instead of the litigation process through the courts as is presently the case. Also there is the need to strengthen the enforcement of the decisions reached through the ADR process by courts.

It is therefore recommended that a hybrid model that combines the best or strength of both systems and avoids their short comings or weaknesses is to be preferred and adopted. 